\title{
Pegylated Interferon Alfa
}

National Cancer Institute

\section{Source}

National Cancer Institute. Pegylated Interferon Alfa. NCI Thesaurus. Code C2491.

A covalent conjugate of recombinant interferon alpha and polyethylene glycol (PEG), used as an antiviral and antineoplastic agent. The biological activity of this agent is derived from its interferon alpha protein moiety. Interferons alfa bind to specific cell-surface receptors, leading to the transcription and translation of genes whose protein products mediate antiviral, antiproliferative, anticancer, and immune-modulating effects. The PEG moiety lowers the clearance of interferon alpha, thereby extending the duration of its therapeutic effects, but may also reduce interferon-mediated stimulation of an immune response. $(\mathrm{NCl} 04)$ 